\title{
Fatigue Properties of a 2 mm AA6060-T6 Butt Weld Produced Using the Hybrid Metal Extrusion \& Bonding (HYB) Process
}

\author{
Lise Sandnes $^{1}$, Øystein Grong ${ }^{2}$, Torgeir Welo ${ }^{1}$, and Filippo Berto ${ }^{1}$ \\ ${ }^{1}$ Norwegian University of Science and Technology \\ ${ }^{2} \mathrm{HyBond}$ AS
}

April 28, 2020

\begin{abstract}
The present investigation is concerned with high-cycle axial fatigue testing of a $2 \mathrm{~mm}$ AA6060-T6 HYB butt weld produced in the solid state using AA6082 filler metal additions. It complements the three-point bend testing and the tensile testing done in two previous studies. Also, optical and scanning electron microscope investigations have been carried out to reveal the macro/microstructure and document possible surface \& root defects deemed to be destructive to fatigue life. In the as-welded condition, the HYB weld suffers from surface irregularities at the weld face and "kissing" bond formation in the root region. Still, these defects are not devastating for the structural integrity. As a matter of fact, the subsequent benchmark testing shows that the fatigue properties surpass those reported for a comparable AA6082-T6 gas metal arc butt weld and fully match those reported for corresponding high-strength laser beam and friction stir weldments.
\end{abstract}

\section{Hosted file}

Fatigue testing of $2 \mathrm{~mm}$ HYB AA6060-T6 butt weld.docx available at https://authorea.com/users/ 314396/articles/445003-fatigue-properties-of-a-2-mm-aa6060-t6-butt-weld-produced-using-thehybrid-metal-extrusion-bonding-hyb-process 